\title{
INSIGHTS INTO THE COLLECTIVE BARGAINING PROCESS IN AN INDIAN SUGAR INDUSTRY: A STUDY
}

\author{
Dr. Anupama Nalkurti ${ }^{1} \square$, Professor G.L. Narayanappa 2 (iD \\ ${ }^{1}$ Academic Consultant, Department of Management, Dravidian University, Kuppam, India \\ ${ }^{2}$ Dean, School of Commerce and Management, Dravidian University, Kuppam, India
}

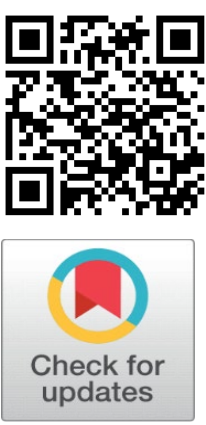

Received 15 November 2021

Accepted 5 December 2021

Published 31 December 2021

\section{CorrespondingAuthor}

Dr. Anupama Nalkurti, anupama.nalkurthi@gmail.com

\section{DOI}

\subsection{1/ijetmr.v8.i12.2021.1060}

Funding: This research received no specific grant from any funding agency in the public, commercial, or not-for-profit sectors.

Copyright: (C) 2021 The Author(s). This is an open access article distributed under the terms of the Creative Commons Attribution License, which permits unrestricted use, distribution, and reproduction in any medium, provided the original author and source are credited.

\begin{abstract}
'JUPITER' sugars India LTD was founded in 1941 in southern India as a private sugar factory. Later it enhanced its production from 1000 TCD to 8500 TCD in the year 1962. It was amalgamating many subunits and multi locational products into its main unit. The company has focused its attention on various projects and substantial resources. Subsequently, they have decided to organize the company into two units one in southern India and one in northern India.

Sugar industry is a vital agro industry largely depends on agriculture in India and is extremely accountable for creating a major impact on rural economy in particular and the country's economic status on broad-spectrum. Sugar production has a yield in the Indian subcontinent since ancient times. Then subsequently evolutes around the globe Moxham (2002). Sugarcane is a native of tropical Indian domain and spread over to the vital segments of world. Sugarcane plantation would be carried out twice in every year in India. The majority of the sugar production in India takes at regional sugar mills NFCSF 2018. Subsequently in the post-independence era India contemplated for overall augmentation of sugar industry Indian Sugar Industry (2019).

The Indian sugar industry is independent in its energy needs and further makes additional exportable power through cogeneration. The different byproducts of sugar industry likewise add to the economic development of the nation to advancing various additional industries. Sugarcane has developed as a multi-product crop utilized as an essential raw material for the manufacture of sugar, ethanol, paper, electricity and besides a cogeneration of subsidiary product.
\end{abstract}

Keywords: Collective Bargaining, Cooperative, TCD, Jupiter Agreement Schedule

\section{INTRODUCTION}

The taking care of dairy cattle of sugarcane is a significant source of biovitality and more demand in rural areas. Molasses is an essential sustain stock for distilleries. The ethanol necessity of the nation is going up progressively. In the sugar industry, creation of power utilizing biogases was the typical option and utilization of biogases as a substitute raw material for wood pulp for monetary and ecological sustainability. 


\section{Importance of Collective Bargaining process}

The word collective purely stipulates that the representatives try to negotiate an agreement for groups of personnel. Bargaining is the process of gathering, presenting demands, discuss, presenting counteroffers, bargain, deceive, threatening, and an entire host of other activities that advances towards the negotiation of an agreement Flippo (1976). The word collective bargaining symbolizes collective negotiations of an agreement between management's representatives on one side and particular workers on the other.

Collective bargaining is a helpful discussion for throwing a light on working conditions and terms of job contract, emoluments and the relationships between the employees and employer of their organization. It is quite successful and aptly adaptable rather than Government policy. It can help in anticipating possible issues and can progress peaceful mechanisms for dealing with them; and finding solutions that consider the priorities and needs of both employers and workers. Sound collective bargaining benefits both administration and employees, and the harmony and stability it advances advantage to all the people in society. Collective bargaining is a vital public administration - it indicates the expanding the consent of the governed by including them in the decisions that affect them directly.

Collective bargaining is an intentional process activity carried to fix the statutes and terms and conditions related to employment. Collective bargaining has the benefit that it settles issues through discourse and consensus rather than through conflict and confrontation.

\section{Select Review of Literature}

Patil (1976) made an attempt through his study towards private and public enterprises and stated that the method of collective bargaining emphasizes about the vital modus operandi for resolving the long pending conflicts in the industry. Further, the employer's representatives and the trade union representatives have also mentioned the same opinion towards the public and private enterprises. The study also stated that, the concept of conciliation is a part of collective bargaining process.

Menon (1983) has conducted a study to probe into the personnel policies inclusive of collective bargaining prevailed in the commercial banks. He has found that the union leaders are greatly influenced by the management representatives for want of materialistic advantages and personal career growth in the organization.

Pencavel (1996) has examined the way in which the judiciary considers the concept of trade union and collective bargaining. The role of unions was also examined. In this study the different activities of the union were also indentified. It is realized that the way of life of the workers can be improved simply by increasing the total productivity. Since, raising the worker's compensation through distributing income from the accrued benefits and profits from the market. In the previous three decades, it is noticed that from certain countries, the lifestyles and living standards of the workers can be enhanced by way of enhanced production targets.

Mohamed (2002) has opined that the concept of collective employment has relationships in public undertakings. Factually, this concept emphasizes the strength of relationship between the unions and management. Further, it also threw a light on personal job relationships with the employees. The group employment 
relationships and the personal job relationships of each employee are specifically identified. The affinity between the two parameters such as (i) employment responsibilities and (ii) financial status between employees and employers are greatly affection the relationship prevailed between them.

Freeman (2012) Collective bargaining acquired ideas and theories from political issues, financial matters, behavioral issues and sociology to shape firm worldview for the how employees' bargain against their managements. It gave a system for understanding how unions can develop an employment bond, similar as other sort of association for prescribed time of efficiency.

Marginson (2016) The approach of collective bargaining is established in the overall thought that workers bound together through negotiated agreements make an overall influence with managements. Collective bargaining documents address meeting the general desires between unions and the management's representatives with respect to agreements on wages, benefits, and timing schedules.

\section{Scope of the study}

The scope of this study is confined to the procedure of collective bargaining in management in 'JUPITER' sugars India Ltd. Only. The outcomes of this study cannot be generalized to any other company.

\section{OBJECTIVES}

The specific objectives of this paper are

1) To assess the contemporary patterns of collective bargaining procedure in 'JUPITER' Sugars India Limited.

2) To measure the level of satisfaction/dissatisfaction of employees/workers towards the contemporary patterns of collective bargaining procedure in 'JUPITER' Sugars India Limited.

3) To identify the reasons for the dissatisfaction of employees/workers respondents towards the contemporary pattern of collective bargaining procedure in 'JUPITER' Sugars India Limited.

4) To offer the feasible ways and means to streamline the contemporary patterns of collective bargaining procedure in 'JUPITER' Sugars India Limited.

\section{RESEARCH METHODOLOGY}

The methodology includes of data collection from primary as well as secondary source. Through the survey method, the firsthand information was collected from 60 sample respondents from the study area.

\section{Sample design and size}

A purposive-cum-convenient sampling technique was followed, and 60 respondents were chosen as sample respondents from the study unit. 


\section{Analysis of the data}

The information collected from the sample respondents was processed and tabulated scientifically and several statistical tools like (i) independent sample ttest; (ii) weighted mean scores; and (iii) ANOVA are calculated at appropriate levels.

\section{The Limitations}

1) The study is confined to only one sugar unit.

2) The size of the sample is 60 only where the number is very meagre.

\section{RESEARCH FINDINGS}

1) The present collective bargaining procedure is making enormous delay for discussion and for finding out the solutions for the problems, since the management or the management representatives have to discharge multiple responsibilities in the organization and the time sparing for attending this procedure is also minute (31.66\%).

2) The management is not at all sticking on to the collective agreements which are compiling in collective bargaining procedure and utterly deviating the collective agreements. As a result, the employees/ workers are forced to be resorted for strike $(28.33 \%)$.

3) Total charter of demands put forth by the workers is not addressed in the collective bargaining process. Only part of them is addressed by the management. Hence, for the next schedule of collective bargaining process, the items to be discussed in the process are becoming huge $(21.66 \%)$

4) In the present procedure of collective bargaining due importance is not given to the voices of workers or workers representatives. Especially any employee/ worker raising matter related to financial one, such workers are not at all allowed to open their voice (18.33\%).

\section{SUGGESTIONS}

1) The process of collective bargaining must be expedited on war footing basis. Time schedules are to fix for discussion and negotiation of each item on scientific basis. For ex: 7 days of time should be fixed for addressing a minor issue in the process of collective bargaining. Similarly, 15 days should be fixed for addressing a major problem or any other problem in the process. The solutions identified in the collective bargaining process should be intimated to the concerned employee within 24 hours of the completion of collective bargaining process. Further, the multiple responsibilities lie on the shoulders of management and management representatives should be decentralized and the same may be entrusted to designated officers. So that the multiple responsibilities lies on the heads of the management and management representatives would be reduced and they can freely concentrate on the various issues to be discussed in collective bargaining.

2) The collective agreements which are compiled with the mutual concern of employees and the management should be uploaded in the company's 
website for want of transparency. So that the unnecessary misunderstandings and deviations between employees and the management can be wiped out.

3) Before entering into the collective bargaining process the total charter of demands demanded by the employees/workers should be transparently incorporated into the agenda of the collective bargaining process and the same may be uploaded into the company's website also. Further, almost all the demands demanded by the employees should be solved without single exception. So that the leftover demands cannot be accumulated to the forth coming process of collective bargaining.

4) Before commencement of the collective bargaining process, the union should collect the each and every individual employee's opinion and pool up the same and can be presented to the operators of this collective bargaining process. Due importance should be given to the voices and ambitions of individual employees. The workers or their representatives who are proposed to participate into the collective bargaining process should be given total freedom to freely represent the problems of their team.

\section{REFERENCES}

"Indian Sugar Industry, (2019) Sugar Industry in India, Sugar Industry, Sugar Industries". www.indianmirror.com. Retrieved -06-04.

"NFCSF - 2018-04-17 National Federation of Cooperative Sugar Factories Limited". Retrieved 2019-06-04. "Cooperative sugar mills seek sops to begin crushing in next season". The Financial Express. Retrieved 2019-06-04.

Dr. A.M. Mohamed Sindhasha : A Ph.D thesis titled (2002) "Employment Relations in public sector and private sector banks in selected districts of Tamil Nadu" was submitted to the Bharathidasan University in the year.

Flippo, E.B., (1976) Principles of Personnel Management, 4th ed., p.487, McGrawHill, International Student Edition,

Freeman, R. B., \& Han, E. (2012). The war against public sector collective bargaining in the US. The Journal of Industrial Relations, 54, 386-408. Retrieved from https://doi.org/10.1177/0022185612442279

John Pencavel, (1996) : The Legal framework for Collective Bargaining in developing countries $\quad$ Retrieved from https://papers.ssrn.com/sol3/papers.cfm?abstract_id=82130

Marginson, P., \& Galetto, M. (2016). Engaging with flexibility and security. Rediscovering the role of collective bargaining. Economic and Industrial Democracy, 37, 95-117 Retrieved from https://doi.org/10.1177/0143831X14538850

Menon, P.K.S. : (1983) "Personnel Management in Banks," Sterling Publishers Pvt. Ltd. New Delhi,

Moxham, Roy (2002-02-07). The Great Hedge of India : The Search for the Living Barrier that Divided a People. Basic Books.

Patil, B. R. (1976) "Collective Bargaining and Conciliation in India", Indian Journal of Industrial Relations, Vol. 12, No. 1, pp. 41-60 Retrieved from https://www.jstor.org/stable/27765576 